\title{
HUBUNGAN ANTARA SECURE ATTACHMENT DENGAN KEMANDIRIAN PADA SISWA KELAS XI SMA/MA AR-RISALAH PADANG
}

\author{
Ifani Candra, Khansha Ulya Leona \\ Universitas Putra Indonesia YPTK Padang \\ email: ifanicandra@yahoo.com
}

\begin{abstract}
The purpose of this study aims to determine the relationship between secure attachment and independence in class X SMA / MA Ar-Risalah padang. The independent variable in this study is secure attachment and the dependent variable in this study is independence. The measuring instrument used in this study is the scale of the secure attachment and the scale of independence. The data collection technique in this study was a simple random sampling technique. The population in this study were grade X students of SMA / MA Ar-Risalah Padang, amounting to 192 people. The sample of the study was 115 students of class X SMA / MA ARRisalah Padang. The validity of thescale secure attachment moves from $\mathrm{ri}_{\mathrm{x}}=0.326$ to $\mathrm{ri}_{\mathrm{x}}=0.942$ and reliability 0.952 . For the scale of independence, move from $\mathrm{ri}_{\mathrm{x}}=0.322$ to $\mathrm{ri}_{\mathrm{x}}=0.810$ and reliability 0.952 . The hypothetical test result is 0.312 with a significant level of 0.001 indicating there is a relationship between secure attachment and independence. The secure attachment amount ofwith independence is $10 \%$ and $90 \%$ is determined by other factors.
\end{abstract}

Keywords: secure attachment, independence, students

\begin{abstract}
Abstrak
Tujuan dari penelitian ini bertujuan untuk mengetahui hubungan antara secure attachment dengan kemandirian pada siswa kelas X SMA/MA Ar-Risalah padang. Variabel bebas pada penelitian ini adalah secure attachment dan variabel terikat pada penelitian ini adalah kemandirian. Alat ukur yang digunakan dalam penelitian ini adalah skala secure attachment dan skala kemandirian. Teknik pengambilan data pada penelitian ini adalah teknik simple random sampling. Populasi pada penelitian ini adalah siswa kelas X SMA/MA Ar-Risalah padang yang berjumlah 192 orang. Sample penelitian berjumlah 115 orang siswa kelas X SMA/MA AR-Risalah Padang. Validitas skala secure attachment bergerak dari $\mathrm{ri}_{\mathrm{x}}=0,326$ sampai dengan $\mathrm{ri}_{\mathrm{x}}=0,942$ dan reliabilitas

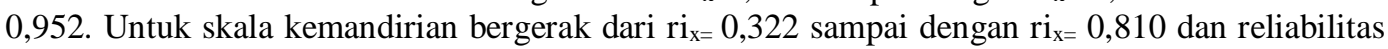
0,952 . Hasil uji hipotetis 0,312 dengan taraf signifikan 0,001 menunjukkan terdapat hubungan antara secure attachment dengan kemandirian. Besar sumbangan secure attachment dengan kemandirian adalah sebesar $10 \%$ dan $90 \%$ ditentukan oleh faktor lain.
\end{abstract}

\section{Kata kunci: secure attachment, kemandirian, siswa}

\section{Pendahuluan}

Setiap lembaga pendidikan, baik pendidikan formal ataupun non formal pasti bertujuan untuk mengembangkan peserta didiknya ke arah yang lebih baik. Salah satu cara agar tujuan tersebut dapat tercapai adalah dengan melaksanakan manajemen 
pendidikan yang berkualitas dalam suatu lembaga pendidikan. Pesantren sebagai model lembaga pendidikan Islam pertama yang mendukung kelangsungan sistem pendidikan nasional, selama ini tidak diragukan lagi kontribusinya dalam rangka mencerdaskan kehidupan bangsa sekaligus mencetak kader-kader intelektual yang siap untuk mengapresiasikan potensi keilmuannya di masyarakat. Pondok pesantren mempunyai peranan yang besar dalam dunia pendidikan, terutama dalam pendidikan Islam (dalam Mursidi, 2016). ${ }^{[6]}$

Mencetak generasi penerus yang cerdas dan berakhlak mulia diperlukan pendidikan yang menyeluruh, dalam arti mencakup semua potensi baik dari aspek kognitif, afektif dan psikomotor. Pondok pesantren sebagai salah satu lembaga pendidikan yang mengkombinasikan ketiga aspek tersebut, tidak hanya menekankan aspek kecerdasan kognitif semata. Akan tetapi juga menekankan pada aspek afektif dan psikomotor, yaitu dengan mengajarkan nilai-nilai dan norma yang sesuai dengan syari'at Islam serta membekali para santri dengan keterampilan-keterampilan yang berguna bagi kehidupan sehari-hari (dalam Mursidi, 2016). ${ }^{[6]}$

Kemandirian merupakan salah satu hal yang penting dikembangkan pada masa remaja (Steinberg dalam Prabowo \& Aswanti, 2014). ${ }^{[1]}$ Masa remaja, seseorang akan mendapat peran serta tanggung jawab baru dalam masyarakat yang belum pernah didapatkan sebelumnya. Oleh karena itu, tuntutan tanggung jawab dari lingkungan mengalami peningkatan. Hal ini membutuhkan kemampuan untuk mengatur dirinya sendiri tanpa pengawasan dari orangtua dan guru (Steinberg dalam Prabowo \& Aswanti, 2014). ${ }^{[11]}$

Menurut Desmita (dalam Puryanti, 2013) ${ }^{[10]}$ kemandirian adalah kemampuan untuk mengendalikan dan mengatur pikiran, perasaan dan tindakan sendiri secara bebas serta berusaha sendiri untuk mengatasi perasaan-perasaan malu dan keragu-raguan. Menurut Mussen (dalam Nurhayati, 2015) ${ }^{[9]}$ kemandirian salah satunya bergantung pada pola asuh dan kelekatan anak pada orang tua.

Secure attachment atau kelekatan yang aman menurut Arsmden dan Greenberg (dalam Mutmainah, 2016) ${ }^{[7]}$ adalah ikatan afeksi antara dua individu yang memiliki intensitas yang kuat. Kelekatan juga membuat remaja tidak melepaskan diri dari ikatan keluarga ketika remaja belajar untuk mengembangkan hubungan diluar keluarga.

Sementara itu, anak dengan kualitas secure attachment lebih mampu menangani tugas yang sulit, tidak cepat berputus asa, dan mandiri, dan akan mengembangkan hubungan yang positif didasarkan pada rasa percaya (trust) pada guru dan teman sebaya. Sebaliknya, orangtua yang tidak menyenangkan akan membuat anak tidak percaya (mistrust) dan mengembangkan kelekatan yang tidak aman (insecure attachment). Insecure attachment dapat membuat anak mengalami berbagai permasalahan, misalnya tidak mampu menyelesaikan tugas, tidak percaya diri, tidak mandiri dan akan mengembangkan hubungan yang negatif didasarkan pada ketidak percayaan (mistrust) pada guru dan teman sebaya (Ervika dalam Nurhayati, 2015). ${ }^{[9]}$

Secure attachment memiliki peranan penting untuk membantu remaja dalam memenuhi tugas-tugas perkembangannya khususnya untuk mencapai kemandirian (Muslimah \& Wahdah dalam Fadhillah \& Faradina, 2016) ${ }^{[4]}$ Attachment dibentuk melalui dukungan emosional dan rasa kedekatan, dari orangtua terhadap remaja.

Attachment atau hubungan yang baik antara orangtua dan remaja akan mendukung remaja untuk menjadi mandiri, sehingga perkembangan kemandirian remaja tidak menghasilkan penolakan atas pengaruh orangtua, justru remaja akan mencari masukan dari orangtua untuk mengambil keputusan (Ws \& Ws dalam Fhadillah \& Faradina, 2016). ${ }^{[4]}$ 
Berdasarkan apa yang telah dikemukakan diatas, peneliti tertarik untuk melakukan penelitian dengan judul "Hubungan Antara Secure Attachment Dengan Kemandirian Pada Siswa Kelas X SMA/MA Ar-Risalah Padang”.

Erikson (dalam Desmita, 2016) ${ }^{[2]}$ menyatakan kemandirian adalah usaha untuk melepas diri dari orang tua dengan maksud untuk menemukan dirinya melalui proses mencari identitas ego yaitu berdiri sendiri. Menurut Chaplin (dalam Desmita 2016) ${ }^{[2]}$ otonomi adalah kebebasan individu manusia untuk memilih untuk menjadi kesatuan yang bisa memerintah, menguasai dan menentukan diri sendiri. Menurut Seifert dan Hoffnung (dalam Desmita, 2016) ${ }^{[2]}$ mendefinisikan otonomi atau kemandirian sebagai "kemampuan mengendalikan dan mengatur pikiran, perasaan dan tindakan sendiri secara bebas serta berusaha sendiri untuk mengatasi perasaan-perasaan malu dan keraguan-keraguan. kemandirian merupakan kemampuan individu untuk bertingkah laku secara seorang diri dan merupakan bagian dari pencapaian otonomi diri pada remaja. Menurut Steinberg (dalam Desmita, 2016) ${ }^{[2]}$ aspek kemandirian terdiri atas:

a. kemandirian emosional (emotional autonomy), yaitu kamandirian yang menyatakan perubahan kedekatan hubungan emosional antar individu, seperti hubungan emosional peserta didik dengan guru atau dengan orang tuanya.

b. Kemandirian tingkah laku (behavioral autonomy), yaitu kemampuan untuk membuat keputusan-keputusan tanpa tergantung pada orang lain dan melakukannnya secara bertanggung jawab.

c. kemandirian nilai (value autonomy), yakni kemampuan memaknai seperangkat prinsip tentang benar dan salah tentang apa yang penting dan apa yang tidak penting.

Sebagai hasil dari proses belajar pencapaian karakter mandiri dipengaruhi oleh banyak faktor, Ali dan Asrori (dalam Suid, Syafrina \& Tursinawati, 2017) mengemukakan bahwa ada empat faktor yang mempengaruhi kemandirian anak, yaitu:

1. Gen atau keturunan orang tua

Orang tua yang memiliki sifat kemandirian tinggi seringkali menurunkan anak yang memiliki kemandirian juga. Namun faktor keturunan ini masih menjadi perdebatan karena ada yang berpendapat bahwa sesungguhnya bukan sifat kemandirian orang tuanya itu menurun kepada anaknya, melainkan sifat orang tuanya muncul berdasarkan cara orang tua mendidik anaknya.

2. Pola asuh orang tua

Cara orang tua mengasuh atau mendidik anak akan mempengaruhi perkembangan kemandirian anak remajanya. Orang tua yang terlalu banyak melarang atau mengeluarkan kata "jangan" kepada anak tanpa disertai dengan penjelasan yang rasional akan menghambat perkembangan kemandirian anak. Sebaliknya, orang tua yang menciptakan suasana aman dalam interaksi keluarganya akan dapat mendorong kelancaran perkembangan anak. Demikian juga, orang tua yang cenderung sering membanding-bandingkan anak yang satu dengan lainnya juga akan berpengaruh kurang baik terhadap perkembangan kemandirian anak.

3. Sistem pendidikan di sekolah

Sistem pendidikan di sekolah adalah sistem pendidikan yang ada di sekolah tempat anak dididik dalam lingkungan formal. Proses pendidikan di sekolah yang tidak mengembangkan demokratisasi pendidikan dan cenderung menekankan indoktrinasi tanpa argumentasi akan menghambat perkembangan kemandirian siswa. Sebaliknya, proses pendidikan di sekolah yang lebih menekankan pentingnya penghargaan terhadap anak dan penciptaan kompetensi positif akan memperlancar perkembangan kemandirian belajar.

4. Sistem kehidupan di masyarakat 
Sistem kehidupan masyarakat yang menekankan lingkungan masyarakat yang aman, menghargai ekspresi potensi remaja dalam bentuk berbagai kegiatan, dan tidak berlaku hierarkis akan merangsang dan mendorong perkembangan kemandirian anak.

Amrsden dan Greenberg (dalam Mutmainah, 2016) ${ }^{[7]}$ menyebutkan terdapat tiga aspek attachment yang juga berfungsi sebagai secure attachment yaitu:

a. Trust (kepercayaan)

Menjelaskan kepercayaan anak bahwa orang tua memahami dan menghormati kebutuhan dan hasrat mereka. Secure attachment dengan orng tua akan membuat anak merasa percaya bahwa orag tua akan selalu ada jika dibutuhkan.

b. Communication (komuniksi)

Menjelaskan persepsi anak bahwa orang tua sensitif dan responsif pada keadaan emosi mereka serta mengukur tingkat dan kualitas keterlibatan dan komunikasi verbal dengan remaja. Orang tua menerapkan secure attachment akan menunjukkan sikap hangat dan sensitif, menggunakan gaya komunikasi yang santai dan fleksibel sehingga membuat anak nyaman dalam menerima dan memeperbaiki masalah emosional yang dihadapinya.

c. Alienation (pengasingan)

Menjelaskan perasaan anak yang merasa diasingkan, marah, dan pengalaman pernah dipisahkan dengan orang tua. Orang tua yang menerapkan secure attachment pada anak tidak akan melakukan pengasingan terhadap anak, mereka akan menerima keadaan anak sehingga anak merasa dicintai, dihargai, dan diperhatikan.

Menurut Benokraitis (dalam Kawuryan, Ahyani \& Rohmah, 2016) ${ }^{[5]}$ menjelaskan ada tiga faktor yang mempengaruhi secure attachmen, yaitu:

a. Peran orang tua

Peran orang tua khususnya ibu sangat penting bagi perkembangan anak. Sensitivitas ibu dalam merespon kebutuhan bayi dihubungkan dengan kelekatan yang aman pada bayi. Orang tua juga berfungsi sebagai figure lekat yang penting dan sistem dukungan saat remaja mengeksplorasi lingkungan sosial yang lebih luas dan kompleks.

b. Komunikasi antara orang tua dengan anak

Secure attachment pada anak sangat penting karena mencerminkan hubungan positif antara orang tua dengan anak dan menyediakan pondasi yang mendukung perkembangan sosioemosional yang sehat. Hubungan positif ini tercipta karena adanya komunikasi antara orang tua dan anak yang baik.

c. Konflik antara orang tua dan anak

Adanya konflik antara orang tua dengan remaja berpengaruh positif untuk perkembangan remaja. Perselisihan kecil dan negoisasi memfasilitasi transisi remaja menjadi individu yang mandiri.

Menurut Hurlock (dalam Sa'adah, 2013) ${ }^{[14]}$ membagi masa remaja menjadi masa remaja awal (13 hingga 16 atau 17 tahun) dan masa remaja akhir (16 atau 17 tahun hingga 18 tahun). Masa remaja awal dan akhir dibedakan oleh Hurlock karena pada masa remaja akhir individu telah mencapai transisi perkembangan yang lebih mendekati masa dewasa.

Sullivan (dalam Sa'adah, 2013) ${ }^{[14]}$ Tahap perkembangan remaja dimulai dari fase praremaja sampai dengan fase remaja akhir. Pada fase-fase ini terdapat beragam ciri khas pada masing-masing fase. yaitu:

1. Fase Praremaja

Periode transisi antara masa kanak-kanak dan adolesens sering sikenal sebagai praremaja oleh profesional dalam ilmu perilaku (Potter \& Perry dalam Sa'adah, 2013 $)^{[14]}$ Menurut Hall seorang sarjana psikologi Amerika Serikat, masa muda (youth or preadolescence) adalah masa perkembangan manusia yang terjadi pada umur 8-12 tahun. 
Fase praremaja ini ditandai dengan kebutuhan menjalin hubungan dengan teman sejenis, kebutuhan akan sahabat yang dapat dipercaya, bekerja sama dalam melaksanakan tugas, dan memecahkan masalah kehidupan, dan kebutuhan dalam membangun hubungan dengan teman sebaya yang memiliki persamaan, kerja sama, tindakan timbal balik, sehingga tidak kesepian (Sunaryo dalam Sa'adah, 2013) ${ }^{[14]}$. Tugas perkembangan terpenting dalam fase praremaja yaitu,belajar melakukan hubungan dengan teman sebaya dengan cara berkompetisi, berkompromi dan kerjasama.

2. Fase Remaja Awal (early adolescence)

Fase remaja awal merupakan fase yang lanjutan dari praremaja. pada fase ini ketertarikan pada lawan jenis mulai nampak. Sehingga, remaja mencari suatu pola untuk memuaskan dorongan genitalnya. Menurut Steinberg (dalam Santrock, 2002: 42) mengemukakan bahwa masa remaja awal adalah suatu periode ketika konflik dengan orang tua meningkat melampaui tingkat masa anak-anak.

Kata pondok merupakan dua kata yang saling berkaitan dan mempunnyai tujuan yang sama sebagai tempat tinggal sementara untuk belajar agama Islam. Kata pondok berasal dari bahasa Arab, yaitu "Funduq" yang berarti ruang tidur, wisma, hotel sederhana. Sedangkan pesantren berasal dari kata "santri" dengan awalan (pe-) dan akhiran (-an) yang berarti tempat tingggal santri. Pada umumnya, pendidikan dan pengajaran di pondok pesantren diberikan secara bandongan atau sistem weton, yaitu kiai membacakan, menerjemahkan, menerangkan, dan mengulas kitab-kitab klasik, sedangkan santri menulis hal-hal penting petuah kiai. Cara bandongan juga disebut dengan halaqoh yang berarti lingkaran murid. Sebab para santri berkelompok belajar di bawah bimbingan seorang guru. Selain cara bandongan, kiai menggunakan cara sorogan, yaitu santri membaca ulang teks yang telah dipelajari baik dihadapan kiai ataupun di hadapan sesama santri. Pengajian sorogan biasanya hanya diberikan kepada santri-santri yang cukup maju khususnya yang berminat untuk menjadi kiai (Mas'ud dalam Zebriyati, 2017). ${ }^{[15]}$

Menurut istilah, pesantren adalah lembaga pendidikan tradisional Islam, tempat para santri belajar agama Islam dan menerapkan moralitas Islam sebagai pedoman. Menurut Imam Bawani M. pesantren adalah lembaga pendidikan dan pengajaran agama Islam, umumnya dengan cara nonklasikal. Istilah pesantren bisa disebut pondok saja atau kata ini digabungkan menjadi pondok pesantren, secara esensial, semua istilah ini menggabungkan makna yang sama. Sesuai dengan namanya, pondok berarti tempat tinggal/menginap (asrama), dan pesantren berarti tempat para santri mengkaji agama islam dan sekaligus di asramakan (Masyhud dalam Zebriyati, 2017). ${ }^{[15]}$

\section{Metodologi Penelitian}

Variabel bebas dalam penelitian ini adalah secure attachment dan variabel terikat adalah kemandirian. Alat ukur yang digunakan dalam penelitian ini ada skala secure attachment dan skal kemandirian. Teknik pengambilan sampel dalam penelitian ini menggunakan teknik simple random sampling. Sampel dalam penelitian ini berjumlah 192 siswa.

Populasi dalam penelitian ini adalah siswa SMA/MA kelas X di Pondok Pesantren Terpadu Pesantren Ar-risalah Padang yang berjumlah 192 orang santri, dari 192 santri 31 siswa dilakukan untuk try out sehingga jumlah populasi santri yang digunakan 115 siswa.

Sampel adalah bagian dari jumlah dan karakteristik yang dimiliki oleh populasi tersebut (Sugiyono, 2014) ${ }^{[13]}$.Menurut Sugiyono teknik sampling adalah teknik yang digunakan untuk menentukan sampel dari populasi. Adapun teknik pengambilan sampel pada penelitian ini adalah simple random sampling, yaitu teknik sampel bila semua 
anggota populasi digunakan sebagai sampel yang berjumlah 115 santri dengan kriteria yaitu siswa harus kelas X SMA/MA Ar-Risalah Padang.

Validitas dalam penelitian ini menggunakan validitas isi (content validity) dan validitas kontruks teoritis untuk mengetahui valid atau tidaknya suatu alat ukur.Validitas isi menunjukkan sejauh mana aitem-aitem mencakup keseluruhan kawasan isi yang hendak diukur. Pengujian validitas alat ukur dilakukan oleh professional judgement melalui proses analisis rasional. Pernyataan yang dicari jawabannya dalam validitas ini adalah sejauh mana aitem-aitem tes mewakili komponen-komponen dalam keseluruhan kawasan isi objek yang hendak diukur (aspek representatif) dan sejauh mana aitem-aitem tes mencerminkan ciri perilaku yang hendak diukur (aspek revalansi).Setelah dilakukan penentuan aitem-aitem skala penelitian, selanjutnya dilakukan uji validitas butir dengan jalan mengkorelasi skor aitem dengan total, sehingga aitem-aitem penelitian layak dijadikan alat ukur penelitian.

Pengukuran validitas konstruksi yang digunakan dalam penelitian ini adalah dengan menggunakan teknik korelasi product moment dengan bantuan SPSS IBM 23,0 (Azwar, $2014^{[1]}$. Peneliti menentukan aitem, valid atau tidaknya alat ukur menggunakan $\mathrm{r}_{\mathrm{xy}} \geq 3,0$ $\left(\right.$ Azwar, 2014 ${ }^{[2]}$. Data skala dikatakan valid jika koefisien korelasi lebih besar atau sama dengan $0,3\left(\mathrm{r}_{\mathrm{xy}} \geq 0,3\right)$ dan sebaliknya aitem skala dikatakan gugur jika koefisien korelasi lebih kecil dari $0,3\left(\mathrm{r}_{\mathrm{xy}} \leq 0,3\right)$.

Reliabilitas sebenarnya mengacu kepada konsistensi atau keterpercayaan hasil ukur, yang mengandung makna kecermatanpengukuran. Pengukuran yang tidak reliabel tidak akan konsisten dari waktu kewaktu (Azwar, 2014) ${ }^{[1]}$. Pengujian reliabilitas dalam penelitian ini mengunakan formulasi alpha cronbach, dengan menggunakan bantuan program IBM SPSS 21.0. Reliabilitas dinyatakan oleh koefisien reliabilitas yang angkanya berada dalam rentang 0 sampai dengan 1 . Semakin tinggi koefisien reliabilitas mendekati angka 1 berarti semakin tinggi reliabilitas. Sebaliknya koefisien yang semakin rendah mendekati 0 berarti semakin rendahnya reliabilitas (Azwar, 2014) ${ }^{[1] .}$ Penghitungan reliabilitas dengan menggunakan bantuan program IBM SPSS 23.0.

Uji normalitas bertujuan untuk mengetahui apakah data dalam penelitian ini sudah terdistribusi sesuai dengan prinsip-prinsip distribusi normal agar dapat digeneralisasikan terhadap populasi. Uji normalitas dilakukan untuk mengetahui apakah sebaran suatu data tersebut normal atau tidak. Uji normalitas sebaran pada penelitian ini dilakukan untuk membuktikan bahwa data semua variabel yang berupa skor-skor yang diperoleh dari hasil penelitian tersebar sesuai dengan kaidah normal. Uji normalitas dalam penelitian ini menggunakan one sample test dari Kolmogorov Smirnov dengan bantuan IBM SPSS 21.0 (Azwar, 2014) ${ }^{[1]}$

Uji linearitas bertujuan untuk membuktikan apakah variabel bebas mempunyai hubungan yang linear dengan variabel terikat. Model statistik yang digunakan untuk melihat linearitas kedua variabel tersebut menggunakan test for linearity dengan bantuan program IBM SPSS 23.0 (Azwar, 2014) $)^{[1]}$

Uji hipotesis bertujuan untuk mengetahui apakah kesimpulan pada sampel dapat berlaku untuk populasi atau dapat digeneralisasi (Priyatno, 2008) ${ }^{[12]}$. Uji hipotesis dalam penelitian ini menggunakan teknik korelasi Product Moment Person untuk mencari hubungan variabel dependen dengan variabel independen.

\section{Hasil Penelitian}

Dari pengolahan data skala secure attachment. Koefesien validitas ditetapkan sebesar $\geq 0,30$ sehingga diperoleh hasil dari jumlah aitem awal 3 pernyataan, gugur 6 aitem sehingga jumlah aitem yang valid dan reliabel adalah 24 pernyataan, dengan nilai corrected item-total correlation berkisar antara 0,326 sampai dengan 0,942. Pengolahan 
data validitas skala kemandirian. Koefesien validitas ditetapkan sebesar $\geq 0,30$ sehingga diperoleh hasil dari jumlah aitem awal 30 pernyataan, gugur 3 aitem sehingga jumlah aitem yang valid dan reliabel adalah 27 pernyataan, dengan nilai corrected item-total correlation berkisar antara 0,322 sampai dengan 0,810 .

Uji normalitas digunakan untuk mengetahui apakah populasi data berdistribusi normal atau tidak. Uji normalitas dalam penelitian ini menggunakan uji KolmogorovSmirnov. Priyatno (2008) ${ }^{[12]}$ menyatakan bahwa data yang dinyatakan berdistribusi normal jika signifikansi (p) lebih besar dari 0,05. Berdasarkan hasil pengolahan data dengan menggunakan program IBM SPSS versi 21.0, maka diperoleh hasil sebagai beriku

Tabel 1. Uji Normalitas Skala Secure Attachment dengan Kemandirian

\begin{tabular}{|c|c|c|c|c|}
\hline Variabel & N & KSZ & $\mathbf{P}$ & Sebaran \\
\hline Secure attachment & 115 & 0,773 & 0,589 & Normal \\
\hline Kemandirian & 115 & 0,714 & 0,687 & Normal \\
\hline
\end{tabular}

Berdasarkan tabel 4.1 di atas, maka diperoleh nilai signifikansi pada secure attachment diperoleh nilai signifikansi sebesar $\mathrm{p}=0,589$ dengan $\mathrm{KSZ}=0,773$, hasil tersebut menunjukan bahwa nilai $\mathrm{p}>0,05$, artinya sebaran skala secure attachment terdistribusi secara normal, sedangkan untuk skala kemandirian sebesar $\mathrm{p}=0,687$ dengan $\mathrm{KSZ}=0,714$ hasil tersebut menunjukan bahwa nilai $\mathrm{p}>0,05$, artinya sebaran skala kemandirian terdistribusi secara normal.

Uji linieritas bertujuan untuk mengetahui apakah dua variabel mempunyai hubungan yang linier atau tidak. Dua variabel dikatakan mempunyai hubungan yang linier bila signifikansi (Linearity) kurang dari 0,05 (Priyatno, 2008) ${ }^{[12]}$. Berdasarkan hasil pengolahan data dengan menggunakan program SPSS versi 21.0 for windows, maka diperoleh hasil sebagai berikut:

Tabel 2. Uji Linieritas Skala Secure Attachment dengan Kemandirian

\begin{tabular}{|c|c|c|c|c|}
\hline $\mathbf{N}$ & $\mathbf{D f}$ & Mean Square & F & Sig (p) \\
\hline 115 & 1 & 538,515 & 13,450 & 0,000 \\
\hline
\end{tabular}

Berdasarkan tabel 4.2 di atas, diperoleh nilai $\mathrm{F}=13,450$ dengan signifikansi sebesar $\mathrm{p}=0,000(\mathrm{p}<0,02)$, artinya varians pada skala secure Attachment dengan kemandirian tergolong linier.

Berikut tabel deskriptif statisitik dari variabel secure attachment dengan kemandirian berdasarkan mean empirik sebagai berikut :

Tabel 3. Descriptive Statistic Skala Secure Attachment dengan kemandirian

\begin{tabular}{|c|c|c|c|c|c|}
\hline Variabel & N & Mean & Std.Deviation & Minimum & Maximum \\
\hline Secure attachment & 115 & 63,35 & 5,073 & 49 & 75 \\
\hline kemandirian & 115 & 80,60 & 6,966 & 55 & 97 \\
\hline
\end{tabular}

Berdasarkan nilai mean empirik, maka dapat dilakukan pengelompokkan yang mengacu pada kriteria pengkategorisasian dengan tujuan menempatkan individu kedalam kelompok-kelompok yang terpisah secara berjenjang menurut suatu kontinum berdasarkan atribut yang diukur (Azwar, 2014) ${ }^{[1]}$, dengan ketentuan sebagai berikut :

Tabel 4. Norma Kategorisasi

\begin{tabular}{|c|c|}
\hline Norma & Kategorisasi \\
\hline$X<(\mu-1,0 \sigma)$ & Tinggi \\
\hline$(\mu-1,0 \sigma) \leq X<(\mu+1,0 \sigma)$ & Sedang \\
\hline$(\mu+1,0 \sigma) \geq X$ & Rendah \\
\hline
\end{tabular}

Keterangan :

$\mathrm{X}$ : Skor mentah sampel

$\mu \quad$ :Mean atau rata-rata 
$\sigma \quad:$ Standar Deviasi

Berdasarkan norma di atas, maka diperoleh kategorisasi subjek penelitian pada variabel secure attachment dengan kemandirian sebagai berikut:

Tabel 5. Kategori Secure Attachment dengan Kemandirian

\begin{tabular}{|c|c|c|c|c|}
\hline Variabel & Skor & Jumlah & Persentase (\%) & Kategori \\
\hline \multirow{3}{*}{$\begin{array}{c}\text { Secure } \\
\text { attachment }\end{array}$} & $\mathrm{X}<58$ & 11 & $10 \%$ & Tinggi \\
\cline { 2 - 5 } & $58 \leq \mathrm{X}<68$ & 81 & $70 \%$ & Sedang \\
\cline { 2 - 5 } & $\mathrm{X} \geq 68$ & 23 & $20 \%$ & Rendah \\
\hline \multirow{3}{*}{ kemandirian } & $\mathrm{X}<74$ & 12 & $10 \%$ & Tinggi \\
\cline { 2 - 5 } & $74 \leq \mathrm{X}<88$ & 85 & $74 \%$ & Sedang \\
\cline { 2 - 5 } & $\mathrm{X} \geq 88$ & 18 & $16 \%$ & Rendah \\
\hline
\end{tabular}

Berdasarkan tabel 4.5 di atas dapat gambaran bahwa 11 orang (10\%) siswa kelas X SMA/MA Ar-Risalah Padang yang memiliki secure attachment yang tinggi, 81 orang (70\%) santri kelas X SMA/MA Ar-Risalah Padang yang memiliki secure attachment yang sedang dan 23 orang (20\%) siswa kelas X SMA/MA Ar-risalah Padang yang memiliki secure attachment yang rendah.

Sementara itu ada 12 orang (10\%) siswa kelas X SMA/MA Ar-Risalah Padang yang memiliki kemandirian yang tinggi, 85 orang (74\%) siswa kelas X SMA/MA Ar-Risalah Padang yang memiliki kemandirian yang sedang dan 18 orang (16\%) siswa kelas X SMA/MA Ar-risalah Padang yang memiliki kemandirian yang rendah.

Besar sumbangan variabel secure attachment terhadap variabel kemandirian dapat ditentukan dengan menggunakan rumus koefisien determinan. Derajat koefisien determinan dicari dengan menggunakan rumus sebagai berikut :

$$
\mathbf{K P}=\mathbf{r}^{2} \cdot 100 \%
$$

Keterangan:

$$
\begin{array}{ll}
\mathrm{KP} & =\text { Nilai Koefisien Determinan } \\
\mathrm{r} & =\text { Nilai Koefisien Korelasi } \\
\mathrm{KP} & =\mathrm{r}^{2} \times 100 \% \\
& =0,312^{2} \times 100 \% \\
& =0,097344 \times 100 \% \\
& =0,097344 \% \\
& =10 \%
\end{array}
$$

Berdasarkan rumus tersebut maka dapat ditentukan bahwa besarnya sumbangan secure attachment terhadap kemandirian adalah sebesar $10 \%$ dan 90\% lagi dipengaruhi oleh faktor lain.

\section{Diskusi}

Berdasarkan hasil uji korelasi Product Moment (Pearson) yang dilakukan dengan bantuan IBM SPSS versi 21.0, dimana level of significant $(\alpha)$ 0,01 dan diperoleh nilai koefisien korelasi $(r)=0,312$ dengan nilai $(p) \operatorname{sig}=0,001$, karena nilai $(p)$ sig $0,001<$ 0,01 maka hipotesis diterima. Hasil ini menunjukkan bahwa terdapat hubungan antara secure attachment dengan kemandirian pada siswa kelas X SMA/MA Ar-Risalah Padang dengan arah positif, artinya semakin tinggi tingkat secure attachment yang dimiliki siswa kelas X SMA/MA Ar-Risalah Padang, maka semakin tinggi pula kemandirian siswa begitu pula sebaliknya, semakin rendah tingkat secure attachment yang dimiliki siswa kelas X SMA/MA Ar-Risalah Padang maka semakin rendah kemandirian siswa. 
Hasil ini sesuai dengan pendapat Allen Et Al (dalam Wiranti, 2013) ${ }^{[15]}$ secure attachment antara remaja dan ibu dapat mempengaruhi perkembangan kemandirian pada remaja tersebut. Hubungan yang positif antara remaja dengan ibu dapat membentuk kemandirian intelektual dan emosi.

Menurut Mussen (dalam Mutmainah,2016) ${ }^{[7]}$ kemandirian salah satunya bergantung pada pola asuh dan kelekatan anak pada orang tua(ibu). Mussen (dalam Puryanti,2015) ${ }^{[10]}$ menyatakan bahwa kemandirian salah satunya bergantung pada kelekatan anak dengan orangtua. Allen et al (dalam Wiranti, 2013 ${ }^{[15]}$ hubungan antara secure attachment dengan beberapa aspek psikososial pada remaja serta kesuksesan dalam membangun kemandirian terkait pula dengan hubungan remaja, ayah dan teman sebaya.

Adapun sumbangan efektif dari variabel secure attachment terhadap kemandirian sebesar $10 \%$ dan $90 \%$ lagi ditentukan oleh sumbangan variabel lain. Beberapa faktor lainnya yang mempengaruhi kemandirian juga dipengaruhi oleh stimulus lingkungannya selain oleh potensi yang telah dimiliki sejak lahir sebagai keturunan dari orangtuanya. Ali \& Asrori (dalam Puryanti, 2013) $)^{[4]}$. Hurlock (dalam Puryanti, 2013) ${ }^{[10]}$ yang berpendapat bahwa faktor-faktor yang mempengaruhi kemandirian adalah pola asuh orangtua, jenis kelamin dan urutan posisi anak.

\section{KESIMPULAN}

Berdasarkan hasil pengumpulan data dan analisis data yang dilakukan peneliti, maka dapat ditarik kesimpulan Hasil ini menunjukkan bahwa terdapat hubungan antara secure attachment dengan kemandirian pada siswa kelas X SMA/MA Ar-Risalah Padang dengan arah positif, artinya semakin tinggi secure attachment yang dimiliki siswa kelas $\mathrm{X}$ SMA/MA Ar-Risalah Padang, maka semakin tinggi pula kemandirian siswa begitu pula sebaliknya, semakin rendah secure attachment yang dimiliki siswa kelas X SMA/MA ArRisalah Padang maka semakin rendah kemandirian siswa. Sumbangan efektif dari variabel secure attachment terhadap kemandirian sebesar 10\% dan 90\% lagi ditentukan oleh sumbangan variabel lain.

Referensi

[1] Azwar, Saifudin. 2013. Penyusunan Skala Psikologi. Yogyakarta : Pustaka Pelajar

[2] Desmita. 2016. Psikologi Perkembangan Peserta Didik. Bandung: Pt Remaja Rosdakarya Offset

[3] Dewi, Audy Ayu Arisha \& Valentina Tience Debora. 2013. Hubungan Kelekatan Orangtua-Remaja Dengan Kemandirian Pada Remaja Di Smkn 1 Denpasar. Jurnal Psikologi Udayana Vol. 1, No. 1, 181-189

[4] Fadhillah, Nurul \& Faradina Syarifah. 2016. Hubungan Kelekatan Orangtua Dengan Kemandirian Remaja SMA Di Banda Aceh. Jurnal Ilmiah Mahasiswa Psikologi Vol. 1, No. 3, 3-34

[5] Kawuryan, Fajar dkk. 2013. Hubungan Antara Secure Attachment Dan Kecerdasan Adversitas Dengan Motivasi Berprestasi Pada Siswa Single Parents. Skripsi. Universitas Muria Kudus

[6] Mursidi, Agus. 2016. Dominasi Kiai Dalam Pendidikan Di Pondok Pesantren Ihya' Ulumiddin. Jurnal Historia Vol. 4, No. 2 
[7] Mutmainah, Fauzul. 2016. Pengaruh Secure Attachment Terhadap Kemandirian Anak Usia Dini Di Ra Muslimat Nu I Belung Ponco Kusumo Malang. Skripsi Universitas Islam Negri Maulana Malik Ibrahim Malang

[8] Nadzir, Ahmad Isham \& Wulandari Nawang Warsi. 2013. Hubungan Religiusitas Dengan Penyesuaian Diri Siswa Pondok Pesantren. Jurnal Psikologi Tabularasa. Universitas Merdeka Malang

[9] Nurhayati, Hani. 2015. Hubungan Kelekatan Aman (Secure Attachment) Anak Pada Orangtua Dengan Kemandirian Anak kelompok B Tk Pkk 37 Dodogan Jatimulyo Dlingo Bantul. Artikel Jurnal Skripsi. Universitas Negeri Yogyakarta

[10] Puryanti Imul. 2013. Hubungan Kelekatan Anak Pada Ibu Dengan Kemandirian Di Sekolah. Skripsi Universitas Negeri Semarang

[11] Prabowo, Raden Dimas Bagus \& Aswanti Mita. 2014. Hubungan Attachment IbuAnak Dan Ayah-Anak Dengan Kemandirian Pada Remaja Akhir. Skripsi. Universitas Indonesia

[12] Priyatno, Dwi. 2008. Mandiri Belajar SPSS. Yogyakarta: Mediako

[13] Sugiyono. 2013. Metode Penelitian Kuantitatif Kualitatif Dan $R \&$ D. Bandung: Alfabeta

[14] Sa'adah, Susan. 2013. Teori Perkembangan Remaja. Tesis. Universitas Muhammadiyah Yogyakarta

[15] Wiranti Ayudhira. 2013. Hubungan Antara Attachment Terhadap Ibu Dengan Kemandirian Pada Remaja Tunarungu. Jurnal Psikologi Pendidikan Dan Perkembangan Volume 02, No. 01

[16] Zebriyaty, Hamizah. 2017. Peranan Pondok Pesantren Darul Qurro Dalam Membangun Karakter Santri Di Desa Kawunganten Lor Kecamatan Kawunganten Kabupaten Cilacap. Skripsi. Universitas Muhammidayah Purwokerto 